\title{
Innovation Clusters Revisited: On Dimensions of Agglomeration, Institution, and Built-Environment
}

\author{
Jianyi Li ${ }^{1}$, Douglas Webster ${ }^{1, *}$, Jianming Cai ${ }^{2,3,4}$ and Larissa Muller 5 \\ 1 School of Geographical Sciences and Urban Planning, Arizona State University, Tempe, AZ 85281, USA; \\ Jianyi.Li@asu.edu \\ 2 Institute of Geographic Sciences and Natural Resources Research, Chinese Academy of Sciences, \\ Beijing 100101, China; caijm@igsnrr.ac.cn \\ 3 Key Laboratory of Regional Sustainable Development Modeling, Chinese Academy of Sciences, \\ Beijing 100101, China \\ 4 School of Resources and Environment, University of Chinese Academy of Sciences, Beijing 100049, China \\ 5 Urban International LLC, Los Altos, CA 94022, USA; urban.intl@gmail.com \\ * Correspondence: Douglas.Webster@asu.edu
}

Received: 26 May 2019; Accepted: 14 June 2019; Published: 17 June 2019

\begin{abstract}
Innovation clusters have been the key concept underlying economic development theory and practice since the concept was re-energized in the 1990s. Worldwide efforts promoting cluster development are supposed to be informed by research on cluster dynamics. The plethora of articles and reports on this globally hyped concept often add to the confusion, calling for a systematic synthesis. In academia, the discussion of innovation clusters is characterized by separate literature dealing with agglomeration, institution, and built-environment. This literature review addresses each of those three dimensions, respectively, by discussing both classic perceptions and potential directions for future research.
\end{abstract}

Keywords: cluster; industrial cluster; innovation cluster

\section{Introduction}

The concept of clusters has a long history dating back to Alfred Marshall's [1] industrial district and was brought to wider public attention by Michael Porter's [2] work on competitive advantage. In spite of multiple neighboring notions without systematic clarifications, such as regional systems of innovation, innovative milieus, learning regions, and growth poles, many analysists seem to have gravitated to the word "cluster" [3,4]. Influence and popularity of the cluster concept are also reflected by its frequent appearance in policy practices worldwide, i.e., Americas [5], Europe [6], Asia [7], Australia [8], and Africa [9]. In fact, economic activity and production are highly concentrated in geographic space [10], illustrated by decidedly affirmative empirical evidence [11]. The cluster concept also gains its reputation through a few well-known examples, e.g., Silicon Valley (U.S.) [12], Emilia-Romagna (Italy) [13], Baden-Württemberg (German) [14], Tsukuba Science City (Japan) [15], and Zhongguancun (China) [16].

Although there is considerable variety concerning the definition of a cluster [17], the major characteristics of the cluster concept can be synthesized as follows: Clusters are not only the spatial concentrations of, but also the localized networks of, specialized organizations including firms (suppliers, customers, competitors), knowledge producing agents (universities, research and training centers), bridging organizations (brokers, consultants, financial organizations and banks), and government agencies [18,19]. The relationships between organizations, either collaboration/competition or commonalities/complementarities, contribute to their linkages and 
interdependencies over which goods, services, and knowledge are exchanged [20-22]. Co-located firms are from the same or related industries [23], or share some common underlying technology or product focus [11]. Interactions between organizations are shaped by cultures and policy frameworks as institutional contexts [22,24]. Competitive advantages of clusters are shaped and enhanced by place-based qualities that attract industry and workers [25].

In much of the literature, the term "cluster" and "innovation cluster" is interchangeable because cluster development is often perceived as an important way to boost innovation [26]. Porter [27] noted that innovation and the commercialization of new technologies take place disproportionately in clusters. By doing a meta-analysis synthesizing 70 papers on the innovation-cluster relationship published from 1988-2014, Fang [28] found that except insignificant or mixed results, positive effects are reported two to three times more frequently than negative effects, based on which she concluded the generally positive effects of clusters on innovation. Some authors think innovation clusters are clusters accommodating innovative industries. Hamdouch [3] indicated that the innovation clusters are often in the high-tech sectors, such as biotechnology, ITC, nanotechnologies, new materials, and space/defense industries. Katz and Wager [29] expanded this industry type approach into research-oriented sectors, highly creative fields, and advanced manufacturing.

The innovation cluster has become one of the most well-known strategic concepts among policy-makers, planners, scholars, and entrepreneurs involved with urban economic development, city building, and innovation facilitation. Worldwide public and private action (normally as the public-private partnership) promoting cluster development need to be justified by constantly improving understanding of cluster dynamics. Given the plethora of articles and reports discussing innovation clusters from various perspectives which often adds to the confusion, there is a need to systematically synthesize current discussions on clusters. Based on reviewing the existing literature, this article addresses three dimensions of innovation clusters, namely agglomeration, institution, and built-environment, respectively. For each dimension, both classic perceptions and current focuses are reviewed to yield the potential future research directions. Since there is an extremely large body literature around clusters or other relevant concepts, this article is not aimed to conduct an exhaustive review covering as much literature as possible, but serves as a concise guide to a few points in cluster research that is worth attention.

\section{Agglomeration Dimension}

\subsection{Agglomertation Effects of Clustering}

Agglomeration economies have long been regarded as the classical theory explaining cluster phenomena. Marshall [30] identified a trinity of external economies of scale: specialization, labor pooling, and knowledge spillover. Later scholars' conceptual contributions, represented by porter's cluster, largely expand on this original statement, even though externalities sometimes are categorized differently, e.g., supply/demand-side benefits in management studies [11] or pecuniary/technological externalities in economic geography [31].

Specialization implies the industrial-complex model, which refers to explicit links and spatial proximity between suppliers and customers leading to reduced search, transportation, and monitoring costs $[10,11,32]$. Locating in a cluster gives firms the opportunity to pursue niche strategies. From the supply side, outsourcing based on local specialized suppliers allows flexible and lean production that avoids the inflexibilities of vertical integration [33]. Folta et al. [34] featured a wider range of service inputs, such as consulting and venture capital. From the demand side, sophisticated demands act as the signal of new trends [35]. Spatial proximity facilitates consumers' visual inspection of intermediary products [36]. In addition to the vertical collaboration, the horizontal competition between firms with similar specializations stimulates diversity and efficiency [20].

Geographical concentration of related firms creates a pooled market for workers with similar skills, lowering search cost and premium risk for employers [37,38]. Employees also benefit from multiple 
job opportunities and the willingness to invest in industry-specific human capital [38]. This availability of multiple options for employer and employee increase the quality of matching between them [39]. In addition to the proximity between firms, local access to universities and associated human capital (graduates and students) significantly attracts knowledge-based firms [40]. Baptista [41] identified the positive impact of human capital density on worker productivity in local clusters.

Knowledge is more likely to spillover between firms and workers in geographic proximity, as Marshall [30] puts: "mysteries of the trade are in the air" [42]. Knowledge spillovers from competing co-located firms, public research infrastructure, and suppliers and customers [43]. Spillover mechanisms include employment turnover, spin-offs, as well as both formal and informal interactions [11,44]. Spatial proximity is important to the transfer of tacit knowledge which is best acquired experientially (face-to-face) [45]. Even for codified knowledge which will be devaluated after widespread dissemination, firms within the cluster can still gain advantages by knowing earlier [46].

Geographic proximity leads to the social capital building. Repeated face-to-face interaction between nearby firms and organizations facilitates trust thus enhancing mutual support and information exchange embedded in informal social networks [20,47,48]. This "untraded interdependencies" [49] partly overlap with the institutional perspective of clusters discussed later in Section 3. In addition, firms in clusters benefit from reputations established by other local firms, which overcomes the information asymmetry regarding firms' quality $[44,50]$.

Larger clusters may bring diseconomies of agglomeration. Folta et al. [34] found that for the performance of U.S. bio-tech firms, marginal benefits to cluster size decline as clusters get large, and then eventually become negative. Excessive co-location and increased competition result in lower output profit, higher input costs (including land/housing, labor, material, and services), unintentional outflow of valuable knowledge, and degradation of environmental quality [34,44,51-53]. Agglomeration diseconomies also occur when a cluster becomes older even without getting larger. Co-locating with the same pool of competitors and suppliers will cause isomorphism in terms of managerial model and product differentiation, putting firms at a competitive disadvantage when technological change is rapid $[2,4,54,55]$.

\subsection{Cluster Spin-Off: Agglomertation Asymmetry and "Borrowed Size"}

Empirical studies have identified that both agglomeration economies and diseconomies have asymmetric effects on different firms. By studying Canadian manufacturing clusters, Pe'er and Keil [32] found that start-ups with less total assets and superior human resources benefit more from local specialization and labor pooling and suffer less from local competition. McCann and Folta [11] found higher benefit from knowledge spillover in clusters for U.S. bio-tech firms with deeper knowledge stocks and younger ages. Moreover, the moderating effects of firm heterogeneity on agglomeration effects could be non-linear. Based on Spanish innovative firm data, Hervas-Oliver et al. [56] concluded that co-located firms with middle innovation capability benefit most from the effect of internal and external knowledge combination. However, there might be no optimal firm characteristic that brings the largest benefits for all dimensions of agglomeration. Knoben et al. [57] identified that for Dutch manufacturing and business service industries, while medium-sized firms benefit most from specialization and urbanization, they received the lowest (negative) impact from regional knowledge intensity. Firms' different organizational form also accounts for agglomeration asymmetry. As Pandit et al. [44] noted, in the London financial service cluster, UNEs (uninational enterprises) benefit more from reputational effects and specialized suppliers, while MNEs (multinational enterprises) are more affected by agglomeration diseconomies. Additinoally, sectoral variations also lead to different clustering effects [58].

Agglomeration literature also features the balance between economies and diseconomies, reflected in the discussion of "borrowed size". It means a small city of metropolitan area exhibits some of the characteristics of a larger one if it is near other population centers [59], because people and business retain advantages of being in smaller settlements (e.g., lower rents and congestion) whilst reaping 
advantages from nearby larger settlements (e.g., access to sizeable market, business services and knowledge, larger and more diverse labor markets) [60]. In other words, accessibility to, rather than presence in, the agglomeration is enough for many firms given the fact that agglomeration diseconomies are largely confined to the metropolis while agglomeration benefits are not so spatially constrained as they have been formerly [61]. However, this discontinuous and regionalized economy is more than a simple scaling-up of agglomeration territories but a result of the tension between the centrifugal force of mobile pecuniary externalities (dispersed supply chain) and centripetal force of immobile technological externalities (localized learning and innovation) [4,31]. In addition, "borrowed size" is not a one-way process. Through interacting with nearby smaller agglomerations, larger ones can also maintain more functions than they could originally support independently [62].

Combining agglomeration asymmetry and "borrowed size", it is fair to assume that as a cluster gets larger and older, the heterogeneity of changing balances between agglomeration benefits and costs will drive a group of firms first move away from the agglomeration core and co-locate in a peripheral area. Who will be better off dispersing depends on the asymmetric distance-decay of agglomeration effects which is different from the agglomeration asymmetry of being in the cluster reviewed above. For example, even though small young firms and big well-endowed firms both benefit more from local knowledge spillover, it is possible that small firms are much more sensitive to distance-decay in terms of knowledge absorption due to lower internal capabilities. Large firms may be more likely to move out because for them, the distance-decay of knowledge externalities is slower than that of agglomeration diseconomies, such as high costs and knowledge leakage. Evidence of "borrowed size" in cluster development exists: for U.S. bio-tech firms, distance from the center of a top-10 cluster matters, but that location within or outside of that cluster, per se, does not [43]. However, more empirical efforts are needed to examine the moderating effects of firms' heterogeneity on the distance-decay of different agglomeration externalities, as well as the meshing of them, so as to systematically inform the possibility and mechanism of cluster spin-off.

The exploration of cluster spin-off dynamic has an implication of cluster promotion alternative to "create out of nothing" or "strengthen the existing one". Starting a new cluster from scratch (ex nihilo) is very difficult [63] and such efforts lead to failures worldwide. New clusters that take advantage of existing strong ones could be the way-out from the dilemma for policy makers [64], e.g., Baden-Württemberg multimedia cluster is the spin-off from traditional engineering cluster in the region [65]. McCann and Folta [11] mentioned isolated firms have strategies to tap into agglomeration benefits, i.e., a branch in the cluster; alliance, and formal relationship with firms and organizations within the cluster. A sub-cluster of firms (potentially) with such abilities can be facilitated to borrow the size of the nearby major cluster. Efforts to promote such sub-cluster should be tailored towards identifying and attracting the original cluster's participants who are more likely to benefit from the "borrowed size" effect. The formation of cluster spin-off also ameliorates agglomeration diseconomies of the original cluster without compromising the function. The original cluster should be more or less matured and have a certain degree of diseconomy, otherwise, the "agglomeration shadow" [66] would exist around a fast-growing cluster where agglomeration benefits overwhelm the costs.

\section{Institutional Dimension}

\subsection{Informal and Formal Institutions of Clusters}

In addition to the dimension of agglomeration, the institutional dimension is needed to develop an independent cluster conceptualization [67]. Institutions are the rules and procedures that structure relations and interactions by enabling and constraining the decision of agents [68]. Informal institutions are unwritten societal norms and moral values, while formal institutions are centrally set codified policies, regulations, and laws [69]. Regarding the cluster concept, the institutional dimension's significance can be understood from two perspectives: (i) the institution is an important determinant underpinning cluster performance based on its role of reducing uncertainty, explaining different 
development paths of clusters worldwide; and (ii) a cluster, as the localized inter-organizational network, itself is a form of institutional arrangement [70]. Based on the framework Parto [71] uses in his institutional analysis of clusters, institutions can be further categorized into behavioral, cognitive, associative, regulative, and constitutive, with the fuzzy boundary between informal and formal institutions.

In terms of informal institutions, behavioral and cognitive institutions are normally referred to as cultures. Firms within the same cluster share similar cultural codes to build trust, social capital, and informal networks which facilitate collaboration, learning, or even alliance formation $[67,70]$. There is no universal set of cultural codes in clusters due to the socio-economic heterogeneity across regions. However, the literature on organizational studies gives a clue on innovation-supportive cultures, such as less bureaucracy [72], risk-taking [73], and alertness to changes [74]. Cultural factors are also emphasized to shape the inter-firm structure and firm performance at the cluster/regional level studies. Saxenian [12] indicated that egalitarianism, spirit of coopetition, entrepreneurial attitudes, and encouragement to job-hopping in Silicon Valley lead to a decentralized business network, flourish of start-ups, and quick response to the changing market and technology. Ibata-Arens [75] highlighted the openness of informal networks and a history of producing high-quality products as crucial cultures making Kyoto a successful life science cluster.

Associative institutions reflect clusters' essence of inter-dependency and often form the major identity of cluster existence (e.g., identification of cluster associations and organizations in cluster mapping efforts, such as the U.S. Cluster Mapping Project, European Cluster Observatory, etc.). It is also the category where the boundary between informal and formal institutions is blurred. The more informal case is that in the apparel and accessory manufacturing cluster in Wenzhou, China, financing is mainly conducted through "Hui" (literally means association) in different villages where borrowing activities rely on reputation and trust along strong kinship and friendship networks [76]. The formal case is the "Joint Venture: Silicon Valley", a neutral forum which brings together business, government, academia, and civic leaders to assess challenges, reach consensus on the best response strategies, and work on solutions together, thus preserving Silicon Valley's world-leading role in innovation and entrepreneurship in a fast-changing global economy [77].

Associative and regulative institutions are what cluster policies try to catalyze (or formally institutionalize) [71]. Different professional cluster policy guides, from OECD's [18] classic proceeding to the Brookings Institution's [78] latest rethinking, all share similar recipes: bridging information symmetry and collaboration networks (collaborative decision-making, industry-industry/industry-research linkage), creating a stable and fair environment for innovation (technical standards, IP framework), infrastructure provision (physical investment and place-making, financial incentives and capital access, knowledge infrastructure for talent development), etc. However, these policy practices, according to the critical reflection in academia, cannot be labelled as an individual policy field named "cluster policy" but should be considered as the combination of existing instruments in traditional industrial, regional, educational, and science and technology policies adopted at higher levels $[64,79,80]$. This nature of cluster policies, combined with Parto's [71] inclusion of constitutive institutions (regarding political regime and global market trend) in his institutional framework of cluster analysis, implies the impact of the supra-cluster environment on cluster institutions.

\subsection{Multi-Level Interaction Perspective of Cluster Institutions}

Local-level cluster institutions should not be analyzed independently from wider institutional environments since embedding associative and regulative institutions in a cluster needs impetus from a higher level of government [71], e.g., some wider regional and national frameworks, such as the Industrial Cluster Project (ICP) in Japan [81]. Meanwhile, clusters could be promoted implicitly by top-down efforts without addressing the cluster concept, e.g., BioRegio' scheme, Germany [82]. A supra-cluster political environment plays an important role, exemplified by the Baden-Württemberg case where successful industrial clustering is ascribed to its autonomous position in Germany and 
former minister-president Lothar's political entrepreneurial effort [64]. Cluster services can be also considered to bridge the institutional void in the wider environment thus attracting firms especially SMEs who lack resources and rely on intermediaries [83]. Empirically, Konstantynova and Lehmann [84] compared cluster institutions across different European countries, then find that clusters in countries rank low in political transformation/contract enforcement/access to credit are more likely to offer activities to remedy these deficiencies (and vice versa).

Cluster institutional interaction exists not only between different levels of formal institutions but also across informal and formal institutions. Under weak formal institutions (e.g., legal protection for properties, banking, and contract enforcement) in developing countries, informal safeguards based on localized social norms are important for geographically proximate firms $[85,86]$, indicating informal institutions of a cluster can also bridge the institutional void in the wider environment. Parto [71] discussed two cases on how cluster cultures are influenced by different levels of formal institutions: (i) in Durban's automotive cluster, South Africa, the shift of national governance ideology from protective self-sufficiency to liberalization brought in international players (e.g., Toyota) whose high production standards create new mental models of domestic producers; and (ii) in Damietta's furniture cluster, Egypt, the officially established Association for Upgrading the Furniture Sector in Damietta (AUFSD) changed cluster members' business attitudes from individualistic to collaborative.

Foregoing discussions on institutional interaction of clusters warrant a systematic analytical framework. Building on frameworks of informal-formal institutions interaction conceptualized in other topics by scholars like Helmke and Levitsky [87], Williamson [88], Grzymala-Busse [89], and Osei-Tutu et al. [90], we add the multi-level perspective to their interaction frameworks for the institutional analysis of clusters (as shown in Figure 1). The basic idea is that the holistic understanding of a cluster's institution requires considering every possible pair of interaction between different kind of institutions (informal and formal) across different levels (cluster and supra-cluster). Variables of strength and direction are assumed to influence the outcome of institutional interaction, similar to that of previous interaction thesis [87-90]. For example, in the case of how clusters bridge the institutional void, the strong cluster-level institutions substitute the weak national institution with convergent goals. In addition to institutional interactions mentioned in the previous two paragraphs, there are more possibilities, e.g., how corruptions as informal institutions in higher-level governance affect the culture and organization of clusters. It should be noted that effects of interaction are mutual, e.g., the establishment of the Shenzhen Special Economic Zone was fueled by China's national opening-up reform but also served as the flagship laboratory demonstration to be learned by the whole country [91].

The implication of this multi-level interaction framework is to provide an alternative way of comparative learning in cluster studies. Due to the global fever of the cluster concept, policy-makers worldwide tend to benchmark successful elements from a few best global practices. However, Hospers and Beugelsdijk [64] criticized that experiences of cluster stories are hardly transferable from one place to another given contingencies on resource capacity, economic structure, culture, etc. Burfitt and Macneill [80] doubted the transferability of cluster initiatives from the implementation perspective, identifying managerial and political challenges in the multi-level and multi-organizational setting. Rather than largely looking at cluster culture and initiatives, per se, the proposed framework calls for major attention on why certain cluster institutions exist and how they function within the context. This focus on learning from relativity rather than absoluteness may be an opportunity in mitigating the tension between generality and specificity in cluster policy-making. In other words, the multi-level interaction framework contributes to the shift from recipe-seeking to procedural inspiration in the comparative learning of cluster practices. 


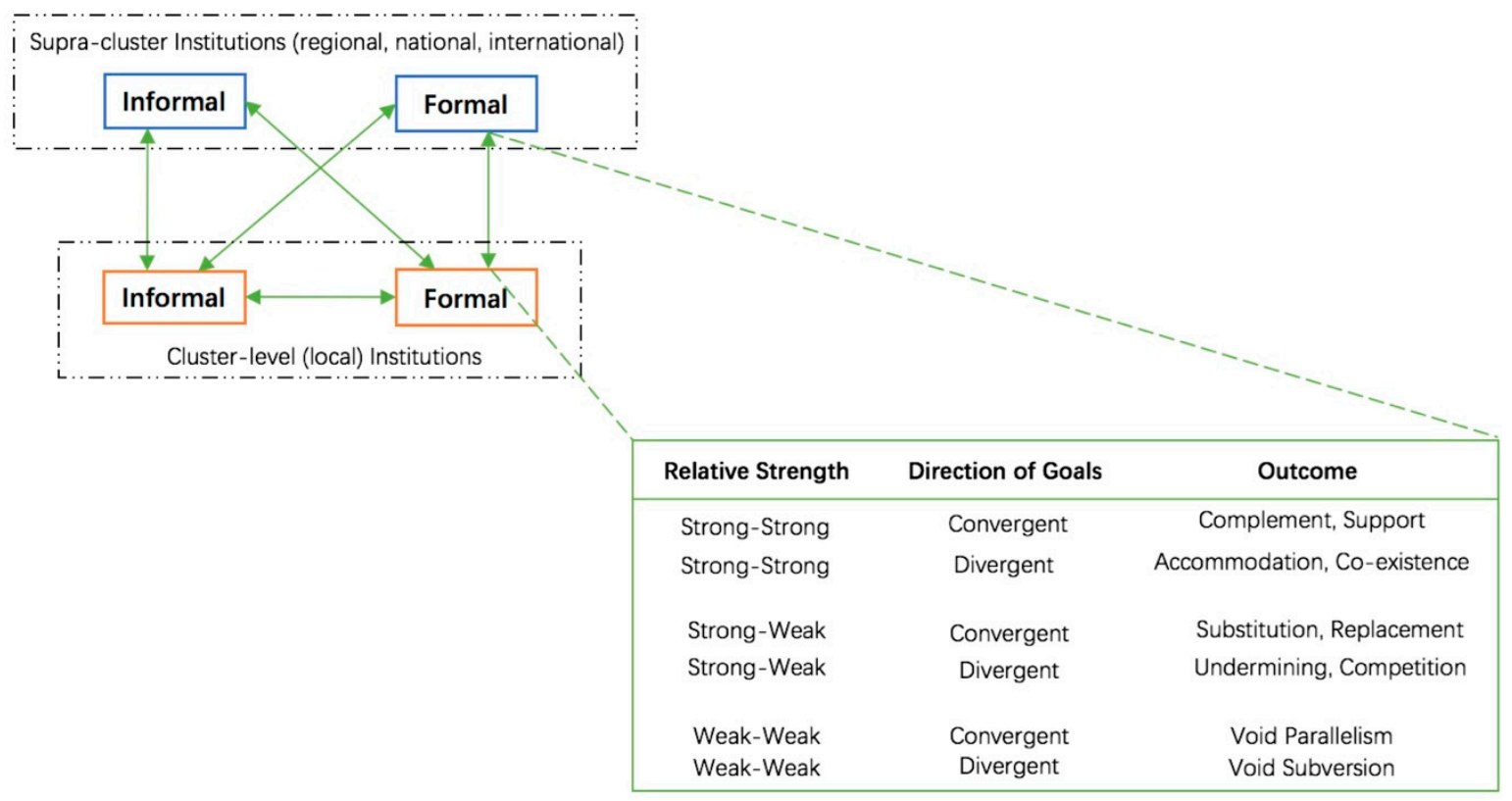

Figure 1. Multi-level interactive framework for cluster institutional analysis, modified from the institutional interaction framework of Osei-Tutu et al. [90] and Williamson [88].

\section{Built-Environment Dimension}

\subsection{From Suburb to the City}

Recently, place-based notions are drawing increasing attention in the discussion of innovation clustering. On the city- or regional- level, knowledge-based urban development (KBUD) emphasizes built-environment factors including leisure and amenity, design and heritage, and density, along with business and administrative environments [92]. On the district- or neighborhood scale, the concept of urban innovation district features "physically compact, transit-accessible, and technically-wired areas offering mixed-use housing, office, and retail, where leading-edge anchor institutes and companies cluster and connect with start-ups, business incubators, and accelerators" [29]. The contemporary inner-city innovation cluster development is exemplified by 22@Barcelona (Spain), One-North (Singapore), and the Boston Seaport District (U.S.). However, they contrast with the suburban model of corporate campus dominated back in the later 20th century, e.g., Stanford Research Park (now Silicon Valley), and Tsukuba Science City (Japan). Behind this shift are changing preference structures and technological and economic dynamics.

The previous suburban model of innovation clusters can be explained by the following factors. Technology parks were encouraged towards the metropolitan periphery along with the postwar suburbanization trend facilitated by expressway expansion and urban decay [63,93]. Castells [63] considered isolated suburban locations (i) keep scientists away from mundane distractions; (ii) are linked to the state's commitment to a "clean start" and spatial equity; and (iii) meet the security needs of military defense agencies which attract the co-location of associated technology producers. By discussing "pastoral capitalism", Mozingo [94] identified (i) the suburban campus image, consisting of a series of low, discrete buildings within a spacious, quiet, and well-landscaped environment, usually projected a sense of good taste, forward-looking optimism, and promise; and (ii) suburban landscapes enable greater control over scientists and validate the use of science for profit, reflecting a closed innovation culture centered on patent secrecy.

For the prevailing inner-urban model of innovation clusters, the key theoretical underpinning is Florida's creative class [95]. Florida claims that the growth of today's knowledge-economy is mainly driven by a pool of "creative" human capital who deliver innovation and skills and, hence, investment and jobs follow them-not the other way around $[25,96]$. Defined by occupations in science and 
technology, design, and high-end service (see what Florida calls the "super-creative core" and "creative professionals"), this group of talents with considerable disposal income and hyper-mobility has distinct locational preference than other workers, that is, pursuing the "quality of places" [95,97]. Florida portrays an image of a vibrant and bohemian downtown district, echoed by Yigitcanlar et al. [98]: mixed-use environment-both in time and space for creative class's blurred work-life boundary and flexible schedule spanning across 24/7; (semi) public "third space" (e.g., café, bookstore, plaza, parks, public transport) for social interaction and networking; authenticity of cultural and recreational amenities (e.g., participatory street events, historical heritage, art/music/sport/theatrical venues, richness in retail and boutique) for (upper-)middle class lifestyle and consumption pattern; openness and tolerance of diversity (in terms of ethnicity, sexual orientation, religion, as well as other alternative lifestyles and sub-cultures ). Moreover, millennials seem to prefer the urban core over previous generations [99], associated with their delayed marriage and low fertility rates, as well as a changing preference against long commuting time and automobile use [93,100]. Based on this line of argument, the built-environment of innovation clusters is important due to its ability to attract and retain human capital.

Florida's discussion has its roots in Jane Jacobs's [101] urbanization externalities emphasizing the knowledge spillover through spontaneous daily interactions and cross-industry complementary collaborations in mixed, dense, and diverse settings. Moreover, there are other factors underlying the locational preference towards urban areas, including firms' decreasing demands for space (due to cloud technology and co-working space), increasing needs for digitally embedded testbeds (e.g., Alphabet's "Sidewalk Lab" in Toronto), and rising open innovation paradigm [102,103].

\subsection{Housing Innovation Clusters}

Emerging empirical studies have identified the impact of place-making on agglomeration and productivity. Hamidi and Zandiatashbar [104] found that walkability, transit accessibility, racial diversity, and regional compactness have positive relationships with innovation productivity across America. In another U.S national study, Zandiatashbar and Hamidi [105] explored that amenities, walkability, and tolerance have positive impacts on the clustering of creative firms and knowledge-intensive business services (KIBS). Proximity to rail transit is proven to generally facilitate firm birth and clustering in Phoenix [106], Dallas [107], and Portland [108]. Meanwhile, Zandiatashbar et al. [109] found that U.S. knowledge and creative firms located in mixed, dense, and walkable transit-oriented developments (TODs) significantly outperform those solely adjacent to transit stations.

Meanwhile, it is more important to directly test whether "quality of place" significantly influences creative class's locational choice-the key hypothesized causality underlying the role of the built-environment dimension. From inter-regional migration perspective, studies in Montreal and Ottawa [110], Birmingham [111], Dublin [112], Poznan [113], and Sweden [114] all indicated that place-making (as "soft factors") do not have a major impact on attracting creative knowledge workers when compared to "hard factors" including housing affordability, career opportunities, and family ties. In terms of intra-region residential preference of the creative class, Frenkel et al.'s [115] study on Tel-Aviv (Israel) and Lawton et al.'s [116] work on Dublin both found that "quality of place" is not as important as classic factors including housing affordability, commuting time, and individual's life cycle. Scholars such as Van Holm [117] found the evidence that the creative class's leisure preferences are not distinctive. Others even consider Florida reverses the causality between the creation of amenities and attraction of workers [118]. Moreover, Florida's profile of creative class lifestyles seems to be oversimplified, as Asheim and Hansen [119] and Frenkel et al. [120] identified different sub-groups of knowledge workers with heterogeneous locational and housing preferences-not necessarily the urban core-and lifestyle orientation.

Although the urbanity has positive impacts on innovation clustering, it is not the decisive factor attracting the necessary human capital, which indicates certain disparities between where 
innovations happen and where innovators choose to reside. Policy implications of the creative class thesis seem to over-emphasize "soft factors", such as cultural and recreational facilities, but neglect the availability and affordability of housing as "hard factors" in the built-environment dimension. Florida's prescriptions were criticized for running the risk of elitism and gentrification [121,122]. For innovation clusters, the high concentration of firms and population makes affordability issues inevitable, e.g., in Silicon Valley, the median housing sale price is $\$ 1.2$ million [123]. By assuming knowledge workers have considerable budgets to live wherever they want, Florida might be too optimistic about their socio-economic status especially for those still early in their careers. Florida is also criticized for only focusing on attracting already-successful professionals [124], thus lacking the consideration of accommodating the future potential creative class.

Therefore, housing availability and affordability issues deserve more attention in the discussion of innovation clusters' built-environment, in terms of both empirical studies and practical solutions. Existing empirical evidence on this matter is limited. Hamidi and Zandiatashbar [104] used high property prices unaffordable for small business to explain their finding on neighborhood compactness' negative impact on innovation productivity across U.S. (although they found regional compactness' impact is positive). When identifying the location pattern of innovation spaces in Beijing, Zheng and Rui [125] found it positively associates with the transit accessibility to affordable rental housing as well as the residential land availability. In terms of policy solutions attracting knowledge workers, approaches that invest on both soft (place-based features) and hard factors (including affordable housing) are proposed [98,126]. However, to match large demands from agglomerations of labor, there is still a great gap in novel provision modes of affordable housing with urban core amenities. In Beijing, due to the resistance from centrally-located district authorities, public affordable housing for Zhongguancun Science Park can only be supplied in unlivable outer suburbs [127]. Meanwhile, Shenzhen's talented worker housing policy resulted in too few public affordable units to surmount housing affordability issues [128].

Researching innovation clusters' housing dimension also contributes to the wider literature on the relationship between housing and local economic development. The capacity and flexibility of local housing systems to deliver enough and a wide range of housing at affordable prices, of the right type, in the right place, and at an acceptable standard, is essential to the economic health of cities $[129,130]$. An insufficient supply of housing will lower local competitiveness by increasing business costs due to higher rents and wages, pushing out the workforce, especially young knowledge workers and lower-paid key workers delivering essential services, and intensifying segregation that goes against social capital building $[124,131,132]$. However, when discussing its linkages to economics, housing has been historically considered as an economic sector (construction and real estate) or even an adjunct to development [133].

\section{Conclusions}

This article discusses the concept of innovation clusters from perspectives of agglomeration, institution, and built-environment, respectively. Based on reviewing the relevant literature, both classic perceptions and future potential directions of each dimension are synthesized. Since certain types of positive and negative externalities of agglomeration have been widely accepted as basic mechanisms of clusters, the literature has turned to explore the asymmetry of agglomeration effects moderated by firm heterogeneities as well as the changing spatial scale of different externalities. Going further, the heterogeneities of firms' distance-sensibilities to different agglomeration effects could be a potential direction for future agglomeration research given its predictive ability for the spatial evolution of clusters. The institutional dimension has been included to fully understand clusters, ranging from discussions on cultural practices to governance modes of clusters. Rather than simply describing each type of institution respectively, scholars came to realize the mutual influence between different institutions. Therefore, frameworks addressing institutional interactions are needed for future studies on cluster institutions. Innovation clusters' built-environment dimension recently drew attention 
largely illuminated by Florida's theory that the creative class is attracted by "quality of place" in the urban core. However, "quality of place" has empirically proven to not be the primary factor attracting knowledge workers compared to traditional hard factors among which housing availability and affordability is featured. Housing seems to be a forgotten field and deserves more attention in the discussion especially considering the potential risk of gentrification by polarizing lifestyle amenities.

Further understanding of innovation clusters could be achieved in the following directions. For quantitative research examining agglomeration effects on firm performance through regression models, interaction effects between cluster proximity, firm heterogeneity, and various externalities need to be estimated, so as to understand the asymmetric distance-decay of agglomeration effects. However, since calculating cluster proximity variables requires firm samples fall outside clusters, how to properly define the cluster boundary could be problematic. Qualitatively, extensive interviews are needed to understand how trade-offs between benefits and costs of being in a cluster influence locational decisions across different types of firms and organizations. Further insights can also be made on how business strategies and operation modes are related to distance-sensitivities to agglomeration effects. Regarding institutional studies of clusters, inspired by previous scholars' frameworks of informal-formal institutional interactions, the holistic understanding of a cluster's institutions needs considering every possible pair of interaction between different kinds of institutions (informal and formal) across different levels (cluster and supra-cluster). In terms of research on the built-environment dimension, in addition to the currently prevailing focus on urban form and amenity, variables of housing availability and affordability should be included when estimating their impacts on innovation productivity and business agglomeration through regression models. More qualitative investigations on novel housing provision modes, housing preferences of employees, as well as individuals' and firms' responses to the changing housing market can be explored in different innovation cluster cases.

The three dimensions of innovation clusters discussed in this article are not totally separated from each other with certain interdependencies. The spatial extent and distance-sensitivity of agglomeration effects could partly depend on institutional arrangements between firms, e.g., alliances and collaborations with firms within clusters may let isolated firms tap into agglomeration benefits. Built-environment matters including community gentrification and housing shortage contribute to agglomeration diseconomies, i.e., higher housing costs lead to higher wages and business costs. Connections could also exist between institution and built-environment, e.g., working and after-working culture influences the types of office and amenities provided; the housing supply is adjusted by policies. Therefore, studying a certain dimension of an innovation cluster should not totally exclude considerations for other dimensions. Ideally, a thorough understanding of a cluster's dynamic is supposed to be gained from the analysis integrating all three dimensions.

Author Contributions: Conceptualization: D.W.; original draft preparation: J.L.; review and editing: D.W., J.C., and L.M.

Funding: This research received no external funding.

Conflicts of Interest: The authors declare no conflict of interest.

\section{References}

1. Marshall, A. Principles of Political Economy; Maxmillan: London, UK, 1890.

2. Porter, M.E. The Competitive Advantage of Nations; Free Press: New York, NY, USA, 1990.

3. Hamdouch, A. Innovation clusters and networks: A critical review of the recent literature. In Proceedings of the 19th European Association for Evolutionary Political Economy Conference, Porto, Portugal, 1-3 November 2007.

4. Polenske, K.R. Clustering in space versus dispersing over space. In The Emerging Digital Economy; Johansson, B., Karlsson, C., Stough, R., Eds.; Springer: Berlin/Heidelberg, Germany, 2006; pp. 35-54. 
5. Feser, E. Industry cluster concepts in innovation policy: A comparison of US and Latin American experience. In Spillover and Innovations: Space, Environment, and the Economy; Maier, G., Sedlacek, S., Eds.; Springer: Wien, Austria, 2005.

6. European Commission. Smart Guide to Cluster Policy; European Commission: Brussels, Belgium, 2016.

7. Ganne, B.; Lecler, Y. Asian Industrial Clusters, Global Competitiveness and New Policy Initiatives; World Scientific: Singapore, 2009.

8. Garrett-Jones, S. From citadels to clusters: The evolution of regional innovation policies in Australia. R D Manag. 2004, 34, 3-16. [CrossRef]

9. Benner, M.C. Cluster Policy as a Development Strategy: Case Studies from the Middle East and North Africa; Working Paper Series in Economics (No, 255); Leuphana Universität Lüneburg, Institut für Volkswirtschaftslehre: Lüneburg, Germany, 2012.

10. Krugman, P. Increasing returns and economic geography. J. Political Econ. 1991, 99, 483-499. [CrossRef]

11. McCann, B.T.; Folta, T.B. Location matters: Where we have been and where we might go in agglomeration research. J. Manag. 2008, 34, 532-565. [CrossRef]

12. Saxenian, A. Regional Advantage: Culture and Competition in Silicon Valley and Route 128; Harvard University Press: Cambridge, MA, USA, 1996.

13. Storper, M. Regional "worlds" of production: Learning and innovation in the technology districts of France, Italy and the USA. Reg. Stud. 1993, 27, 433-455. [CrossRef]

14. Cooke, P.; Morgan, K. The regional innovation system in Baden-Wurttemberg. Int. J. Technol. Manag. 1994, 9 , 394-429.

15. Bloom, J.L.; Asano, S. Tsukuba science city: Japan tries planned innovation. Science 1981, 212, $1239-1247$. [CrossRef] [PubMed]

16. Tan, J. Growth of industry clusters and innovation: Lessons from Beijing Zhongguancun Science Park. J. Bus. Ventur. 2006, 21, 827-850. [CrossRef]

17. Martin, R.; Sunley, P. Slow convergence? The new endogenous growth theory and regional development. Econ. Geogr. 1998, 74, 201-227. [CrossRef]

18. Organisation for Economic Co-operation and Development. Boosting Innovation: The Cluster Approach; OECD: Paris, France, 1999.

19. Van den Berg, L.; Braun, E.; Van Winden, W. Growth clusters in European cities: An integral approach. Urban Stud. 2001, 38, 185-205. [CrossRef]

20. Porter, M.E. Clusters and the new economics of competition. Harv. Bus. Rev. 1998, 76, 77-90.

21. Porter, M.E. Location, competition, and economic development: Local clusters in a global economy. Econ. Dev. Q. 2000, 14, 15-34. [CrossRef]

22. Malmberg, A.; Power, D. True clusters: A severe case of conceptual headache. In Clusters in Regional Development: Critical Reflections and Explorations; Asheim, B., Cooke, P., Martin, R., Eds.; Routledge: London, UK, 2006; pp. 50-68.

23. Bell, G.G. Clusters, networks, and firm innovativeness. Strateg. Manag. J. 2005, 26, 287-295. [CrossRef]

24. Lundvall, B.A. National Systems of Innovation: An Analytical Framework; Pinter: London, UK, 1992.

25. Esmaeilpoorarabi, N.; Yigitcanlar, T.; Guaralda, M. Place quality and urban competitiveness symbiosis? A position paper. Int. J. Knowl. Based Dev. 2016, 7, 4-21. [CrossRef]

26. Preissl, B.; Solimene, L. Dynamics of Clusters and Innovation; Physica-Verlag: Heidelberg, Germany, 2003.

27. Porter, M.E. Innovation: Location matters. MIT Sloan Manag. Rev. 2001, 42, 28-36.

28. Fang, L. Do clusters encourage innovation? A meta-analysis. J. Plan. Lit. 2015, 30, 239-260. [CrossRef]

29. Katz, B.; Wagner, J. The Rise of Innovation Districts: A New Geography of Innovation in America; Brookings Institution: Washington, DC, USA, 2014.

30. Marshall, A. Industry and Trade: A Study of Industrial Technique and Business Organization; Macmillan: London, UK, 1919.

31. Phelps, N.A. Clusters, dispersion and the spaces in between: For an economic geography of the banal. Urban Stud. 2004, 41, 971-989. [CrossRef]

32. Pe'er, A.; Keil, T. Are all startups affected similarly by clusters? Agglomeration, competition, firm heterogeneity, and survival. J. Bus. Ventur. 2013, 28, 354-372. [CrossRef]

33. Glaeser, E.L.; Kerr, W.R.; Ponzetto, G.A. Clusters of entrepreneurship. J. Urban Econ. 2010, 67, $150-168$. [CrossRef] 
34. Folta, T.B.; Cooper, A.C.; Baik, Y.S. Geographic cluster size and firm performance. J. Bus. Ventur. 2006, 21, 217-242. [CrossRef]

35. Von Hippel, E. The Sources of Innovation; Oxford University Press: Oxford, UK, 1988.

36. Stahl, K. Differentiated products, consumer search, and locational oligopoly. J. Ind. Econ. 1982, 31, 97-113. [CrossRef]

37. Baptista, R.; Swann, P. Do firms in clusters innovate more? Res. Policy 1998, 27, 525-540. [CrossRef]

38. Rotemberg, J.J.; Saloner, G. Competition and human capital accumulation: A theory of interregional specialization and trade. Reg. Sci. Urban Econ. 2000, 30, 373-404. [CrossRef]

39. Helsley, R.W.; Strange, W.C. Agglomeration economies and urban capital markets. J. Urban Econ. 1991, 29, 96-112. [CrossRef]

40. Baptista, R.; Mendonça, J. Proximity to knowledge sources and the location of knowledge-based start-ups. Ann. Reg. Sci. 2010, 45, 5-29. [CrossRef]

41. Baptista, R. Productivity and the density of local clusters. In Innovation Clusters and Interregional Competition; Bröcker, J., Dohse, D., Soltwedel, R., Eds.; Springer: Berlin/Heidelberg, Germany, 2003; pp. 163-181.

42. Wennberg, K.; Lindqvist, G. The effect of clusters on the survival and performance of new firms. Small Bus. Econ. 2010, 34, 221-241. [CrossRef]

43. Maine, E.M.; Shapiro, D.M.; Vining, A.R. The role of clustering in the growth of new technology-based firms. Small Bus. Econ. 2010, 34, 127-146. [CrossRef]

44. Pandit, N.R.; Cook, G.A.; Wan, F.; Beaverstock, J.V.; Ghauri, P.N. The economies and diseconomies of industrial clustering: Multinational enterprises versus uninational enterprises. Manag. Int. Rev. 2018, 58, 935-967. [CrossRef]

45. Gertler, M.S. Tacit knowledge in production systems: How important is geography. In The Economic Geography of Innovation; Polenske, K.R., Ed.; Cambridge University Press: Cambridge, UK, 2007; pp. 87-111.

46. Howells, J.R. Tacit knowledge, innovation and economic geography. Urban Stud. 2002, 39, 871-884. [CrossRef]

47. Granovetter, M. Economic action and social structure: The problem of embeddedness. Am. J. Sociol. 1985, 91, 481-510. [CrossRef]

48. Hendry, C.; Brown, J. Organizational networking in UK biotechnology clusters. Br. J. Manag. 2006, 17, 55-73. [CrossRef]

49. Storper, M. The resurgence of regional economies, ten years later: The region as a nexus of untraded interdependencies. Eur. Urban Reg. Stud. 1995, 2, 191-221. [CrossRef]

50. Gilbert, B.A.; McDougall, P.P.; Audretsch, D.B. Clusters, knowledge spillovers and new venture performance: An empirical examination. J. Bus. Ventur. 2008, 23, 405-422. [CrossRef]

51. Myles Shaver, J.; Flyer, F. Agglomeration economies, firm heterogeneity, and foreign direct investment in the United States. Strateg. Manag. J. 2000, 21, 1175-1193. [CrossRef]

52. Zheng, X.P. Determinants of agglomeration economies and diseconomies: Empirical evidence from Tokyo. Socio-Econ. Plan. Sci. 2001, 35, 131-144. [CrossRef]

53. Lavie, D. The competitive advantage of interconnected firms: An extension of the resource-based view. Acad. Manag. Rev. 2006, 31, 638-658. [CrossRef]

54. Stuart, T.; Sorenson, O. The geography of opportunity: Spatial heterogeneity in founding rates and the performance of biotechnology firms. Res. Policy 2003, 32, 229-253. [CrossRef]

55. Chen, L.C. The governance and evolution of local production networks in a cluster: The case of Taiwan's machine tool industry. GeoJournal 2011, 76, 605-622. [CrossRef]

56. Hervas-Oliver, J.L.; Sempere-Ripoll, F.; Rojas Alvarado, R.; Estelles-Miguel, S. Agglomerations and firm performance: Who benefits and how much? Reg. Stud. 2018, 52, 338-349. [CrossRef]

57. Knoben, J.; Arikan, A.; van Oort, F.; Raspe, O. Agglomeration and firm performance: One firm's medicine is another firm's poison. Environ. Plan. A 2016, 48, 132-153. [CrossRef]

58. Beaudry, C.; Swann, G.P. Firm growth in industrial clusters of the United Kingdom. Small Bus. Econ. 2009, 32, 409-424. [CrossRef]

59. Alonso, W. Urban zero population growth. Daedalus 1973, 109, 191-206.

60. Phelps, N.A.; Fallon, R.J.; Williams, C.L. Small firms, borrowed size and the urban-rural shift. Reg. Stud. 2001, 35, 613-624. [CrossRef]

61. Parr, J.B. Agglomeration economies: Ambiguities and confusions. Environ. Plan. A 2002, 34, 717-731. [CrossRef] 
62. Meijers, E.J.; Burger, M.J. Stretching the concept of 'borrowed size'. Urban Stud. 2017, 54, 269-291. [CrossRef]

63. Castells, M. Technopoles of the World: The Making of 21st Century Industrial Complexes; Routledge: New York, NY, USA, 2014.

64. Hospers, G.J.; Beugelsdijk, S. Regional cluster policies: Learning by comparing? Kyklos 2002, 55, 381-402. [CrossRef]

65. Fuchs, G.; Wolf, H.G. The emergence of industrial clusters for multimedia. A comparison of California, Ireland, and Baden-Württemberg. Curr. Politics Econ. Eur. 1998, 8, 225-255.

66. Krugman, P. On the number and location of cities. Eur. Econ. Rev. 1993, 37, 293-298. [CrossRef]

67. Gareev, T.R. Clusters in the institutional perspective: On the theory and methodology of local socioeconomic development. Balt. Reg. 2012, 3, 4-24. [CrossRef]

68. Edquist, C.; Johnson, B.H. Institutions and organizations in systems of innovation. In Systems of Innovation: Technologies, Institutions and Organizations; Edquist, C., Ed.; Cassell: London, UK, 1997; pp. 41-63.

69. North, D.C. Institutions, Institutional Change and Economic Performance; Cambridge University Press: New York, NY, USA, 1990.

70. Bembenek, B. Institutional dimension of business cluster. Eur. Sci. J. 2015, 11, 13-32.

71. Parto, S. Innovation and economic activity: An institutional analysis of the role of clusters in industrializing economies. J. Econ. Issues 2008, 42, 1005-1030. [CrossRef]

72. Shane, S.A. Why do some societies invent more than others? J. Bus. Ventur. 1992, 7, 29-46. [CrossRef]

73. Claver, E.; Llopis, J.; Garcia, D.; Molina, H. Organizational culture for innovation and new technological behavior. J. High Technol. Manag. Res. 1998, 9, 55-68. [CrossRef]

74. Rothwell, R.; Wissema, H. Technology, culture and public policy. Technovation 1986, 4, 91-115. [CrossRef]

75. Ibata-Arens, K. The Kyoto model of innovation and entrepreneurship: Regional innovation systems and cluster culture. Prometheus 2008, 26, 89-109. [CrossRef]

76. Cai, J. Development and Transformation of Wenzhou Model from the Perspective of Social Capital. Ph.D. Thesis, Shanghai Academy of Social Sciences, Shanghai, China, 2010.

77. Benner, C. Learning communities in a learning region: The soft infrastructure of cross-firm learning networks in Silicon Valley. Environ. Plan. A 2003, 35, 1809-1830. [CrossRef]

78. Donahue, R.; Parilla, J.; McDearman, B. Rethinking Cluster Initiatives; Brookings Institution: Washington, DC, USA, 2018.

79. Nauwelaers, C. Path-dependency and the role of institutions in cluster policy generation. In Cluster Policies-Cluster Development; Mariussen, A., Ed.; Nordregio: Stockholm, Sweden, 2001; pp. 93-107.

80. Burfitt, A.; Macneill, S. The challenges of pursuing cluster policy in the congested state. Int. J. Urban Reg. Res. 2008, 32, 492-505. [CrossRef]

81. Nishimura, J.; Okamuro, H. Subsidy and networking: The effects of direct and indirect support programs of the cluster policy. Res. Policy 2011, 40, 714-727. [CrossRef]

82. Fromhold-Eisebith, M.; Eisebith, G. How to institutionalize innovative clusters? Comparing explicit top-down and implicit bottom-up approaches. Res. Policy 2005, 34, 1250-1268. [CrossRef]

83. Schrammel, T. Bridging the institutional void: An analytical concept to develop valuable cluster services. Manag. Rev. 2013, 24, 114-132. [CrossRef]

84. Konstantynova, A.; Lehmann, T. Cluster activities in different institutional environments. Case studies of ICT-Clusters from Austria, Germany, Ukraine and Serbia. Adm. Sci. 2017, 7, 11. [CrossRef]

85. Bell, S.J.; Tracey, P.; Heide, J.B. The organization of regional clusters. Acad. Manag. Rev. 2009, 34, 623-642.

86. Geng, X.; Huang, K.G. Informal institutions and the geography of innovation: An integrative perspective. In Global Innovation and Entrepreneurship; Little, S.E., Go, F.M., Poon, T.S., Eds.; Palgrave Macmillan: Basingstoke, UK, 2017; pp. 61-78.

87. Helmke, G.; Levitsky, S. Informal institutions and comparative politics: A research agenda. Perspect. Politics 2004, 2, 725-740. [CrossRef]

88. Williamson, C.R. Informal institutions rule: Institutional arrangements and economic performance. Public Choice 2009, 139, 371-387. [CrossRef]

89. Grzymala-Busse, A. The best laid plans: The impact of informal rules on formal institutions in transitional regimes. Stud. Comp. Int. Dev. 2010, 45, 311-333. [CrossRef]

90. Osei-Tutu, P.; Pregernig, M.; Pokorny, B. Interactions between formal and informal institutions in community, private and state forest contexts in Ghana. For. Policy Econ. 2015, 54, 26-35. [CrossRef] 
91. Zhang, J. From Hong Kong's capitalist fundamentals to Singapore's authoritarian governance: The policy mobility of neo-liberalising Shenzhen, China. Urban Stud. 2012, 49, 2853-2871. [CrossRef]

92. Yigitcanlar, T.; Velibeyoglu, K. Knowledge-based urban development: The local economic development path of Brisbane, Australia. Local Econ. 2008, 23, 195-207. [CrossRef]

93. Morisson, A. Innovation Districts: A Toolkit for Urban Leaders; CreateSpace: Scotts Valley, CA, USA, 2015.

94. Mozingo, L. Pastoral Capitalism: A History of Corporate Landscapes; MIT Press: Cambridge, MA, USA, 2011.

95. Florida, R. The Rise of the Creative Class: Revisited; Basic Books: New York, NY, USA, 2014.

96. Tomaney, J.; Bradley, D. The economic role of mobile professional and creative workers and their housing and residential preferences: Evidence from North East England. Town Plan. Rev. 2007, 78, 511-530. [CrossRef]

97. Florida, R. Cities and the Creative Class; Routledge: New York, NY, USA, 2005.

98. Yigitcanlar, T.; Baum, S.; Horton, S. Attracting and retaining knowledge workers in knowledge cities. J. Knowl. Manag. 2007, 11, 6-17. [CrossRef]

99. Frey, W.H. The Millennial Generation: A Demographic Bridge to America's Diverse Future; Brookings Institution: Washington, DC, USA, 2018.

100. Urban Land Institute. America in 2013: A ULI Survey of Views on Housing, Transportation, and Community 2013; Urban Land Institute: Washington, DC, USA, 2013.

101. Jacobs, J. The Economy of Cities; Random House: New York, NY, USA, 1969.

102. Cohen, B.; Muñoz, P. The Emergence of the Urban Entrepreneur: How the Growth of Cities and the Sharing Economy Are Driving a New Breed of Innovators; ABC-CLIO: Santa Barbara, CA, USA, 2016.

103. Wagner, J.; Watch, D. Innovation Space: The New Design of Work; Brookings Institution: Washington, DC, USA, 2017.

104. Hamidi, S.; Zandiatashbar, A. Does urban form matter for innovation productivity? A national multi-level study of the association between neighbourhood innovation capacity and urban sprawl. Urban Stud. 2019, 56, 1576-1594. [CrossRef]

105. Zandiatashbar, A.; Hamidi, S. Impacts of transit and walking amenities on robust local knowledge economy. Cities 2018, 81, 161-171. [CrossRef]

106. Credit, K. Transit-oriented economic development: The impact of light rail on new business starts in the Phoenix, AZ Region, USA. Urban Stud. 2018, 55, 2838-2862. [CrossRef]

107. Yu, H.; Jiao, J.; Houston, E.; Peng, Z.R. Evaluating the relationship between rail transit and industrial agglomeration: An observation from the Dallas-fort worth region, TX. J. Transp. Geogr. 2018, 67, 33-52. [CrossRef]

108. Chatman, D.G.; Noland, R.B.; Klein, N.J. Firm births, access to transit, and agglomeration in Portland, Oregon, and Dallas, Texas. Transp. Res. Rec. 2016, 2598, 1-10. [CrossRef]

109. Zandiatashbar, A.; Hamidi, S.; Foster, N.; Park, K. The missing link between place and productivity? The impact of transit-oriented development on the knowledge and creative economy. J. Plan. Educ. Res. 2019. [CrossRef]

110. Darchen, S.; Tremblay, D.G. What attracts and retains knowledge workers/students: The quality of place or career opportunities? The cases of Montreal and Ottawa. Cities 2010, 27, 225-233. [CrossRef]

111. Brown, J. Home from Home? Locational choices of international "creative class" workers. Eur. Plan. Stud. 2015, 23, 2336-2355. [CrossRef]

112. Murphy, E.; Redmond, D. The role of 'hard' and 'soft' factors for accommodating creative knowledge: Insights from Dublin's 'creative class'. Ir. Geogr. 2009, 42, 69-84. [CrossRef]

113. Brown, J.; Mczyski, M. Complexcities: Locational choices of creative knowledge workers. Built Environ. 2009, 35, 238-252. [CrossRef]

114. Niedomysl, T.; Hansen, H.K. What matters more for the decision to move: Jobs versus amenities. Environ. Plan. A 2010, 42, 1636-1649. [CrossRef]

115. Frenkel, A.; Bendit, E.; Kaplan, S. Residential location choice of knowledge-workers: The role of amenities, workplace and lifestyle. Cities 2013, 35, 33-41. [CrossRef]

116. Lawton, P.; Murphy, E.; Redmond, D. Residential preferences of the 'creative class'? Cities 2013, 31, 47-56. [CrossRef]

117. Van Holm, E.J. Leisure choices of the creative class. Cities 2014, 41, 38-43. [CrossRef] 
118. Shearmur, R. L'aristocratie du savoir et son tapis rouge. Quelques réflexions sur les thèses de Richard Florida. In La Compétitivité Urbaine à L'ère de la Nouvelle Économie: Enjeux et Défis; Tremblay, D.-G.T.R., Ed.; Presses de l'Université du Québec: Québec, QC, Canada, 2006; pp. 285-303.

119. Asheim, B.; Hansen, H.K. Knowledge bases, talents, and contexts: On the usefulness of the creative class approach in Sweden. Econ. Geogr. 2009, 85, 425-442. [CrossRef]

120. Frenkel, A.; Bendit, E.; Kaplan, S. The linkage between the lifestyle of knowledge-workers and their intra-metropolitan residential choice: A clustering approach based on self-organizing maps. Comput. Environ. Urban Syst. 2013, 39, 151-161. [CrossRef]

121. Leslie, D. Creative cities? Geoforum 2005, 4, 403-405. [CrossRef]

122. Wyly, E.; Hammel, D. Mapping neoliberal American urbanism. In Gentrification in a Global Context: The New Urban Colonialism; Atkinson, R., Bridge, G., Eds.; Routledge: London, UK, 2005; pp. 18-38.

123. Brinklow, A. Silicon Valley Has the Highest Housing Costs in the U.S.; Curbed: San Francisco, CA, USA, 2019.

124. Berry, M. Melbourne-Is there life after Florida? Urban Policy Res. 2005, 23, 381-392. [CrossRef]

125. Zheng, S.; Rui, D. Where are innovation spaces in Beijing? A mixed logit model to estimate innovation space location choice. In Proceedings of the 2018 Book of Accepted Abstracts of ACSP Annual Conference, Buffalo, NY, USA, 25-28 October 2018.

126. Yigitcanlar, T. Technology and the City: Systems, Applications and Implications; Routledge: London, UK, 2016.

127. Miao, J.T. Housing the knowledge economy in China: An examination of housing provision in support of science parks. Urban Stud. 2017, 54, 1426-1445. [CrossRef]

128. Morrison, N. Building talented worker housing in Shenzhen, China, to sustain place competitiveness. Urban Stud. 2014, 51, 1539-1558. [CrossRef]

129. Gibb, K.; O'Sullivan, T.; Glossop, G. Home Economics: How Housing Shapes City Economies; Housing Corporation: Center for Research and Market Intelligence: London, UK, 2008.

130. Glossop, C. Housing and Economic Development: Moving forward Together; Housing Corporation: Center for Research and Market Intelligence: London, UK, 2008.

131. Barker, K. The Barker Review of Housing Supply; The Stationery Office: London, UK, 2004.

132. DTZ Consulting \& Research. Housing. Economic Development and Productivity: Literature Review. A Report for The Department of Trade and Industry; DTZ: Los Angeles, CA, USA, 2006.

133. Harris, R.; Arku, G. Housing and economic development: The evolution of an idea since 1945. Habitat Int. 2006, 30, 1007-1017. [CrossRef] 